Article

\title{
Trends and Variability in Aerosol Optical Depth over North China from MODIS C6 Aerosol Products during 2001-2016
}

\author{
Peng Wang ${ }^{1, *}\left(\mathbb{D}\right.$, Shangjun Ning ${ }^{1}$, Jiageng Dai ${ }^{1}$, Jingmin Sun ${ }^{1}$, Mingjia Lv ${ }^{2}$, Qingli Song ${ }^{1, *}$, \\ Xin Dai ${ }^{1}$, Jinrong Zhao ${ }^{1}$ and Dajiang Yu ${ }^{1}$ \\ 1 Longfengshan Atmospheric Background Regional Station, Heilongjiang Meteorological Administration, \\ Harbin 150209, China; ningsj163@163.com (S.N.); daijiageng1314@163.com (J.D.); sunjm2011@163.com (J.S.); \\ 53549473@163.com (X.D.); zhao_lfs@163.com (J.Z.); yu_dajiang@163.com (D.Y.) \\ 2 Jiamusi Meteorological Satellite Ground Station, Heilongjiang Meteorological Administration, \\ Jiamusi 154000, China; jiajia_cynthia@163.com \\ * Correspondence: wangpeng7123729@163.com (P.W.); songqingli@yeah.net (Q.S.); \\ Tel./Fax: +86-451-5359-0650 (P.W.)
}

Received: 11 October 2017; Accepted: 10 November 2017; Published: 15 November 2017

\begin{abstract}
This study analyzed the variability and trend in aerosol optical depth (AOD) over North China using the latest MODIS/Terra C6 merged Dark Target/Deep Blue AOD monthly data at $550 \mathrm{~nm}$ from 2001 to 2016. The spatial distribution of the annual mean AOD was generally characterized by two prominent high-value centers located in the industrially and economically developed areas of the North China Plain and East China, and the dust aerosol-dominated areas of southern Xinjiang. The seasonally averaged AOD reached its maximum in spring $(0.430 \pm 0.049)$, followed by summer $(0.356 \pm 0.035)$ and winter $(0.282 \pm 0.039)$, with the minimum occurring in autumn $(0.219 \pm 0.022)$. There were notable long-term annual trends in AOD in different regions over North China during 2001-2016: a decreasing AOD trend was found in Qinghai Tibet $(-0.015 \pm 0.010 /$ decade), Northwest China $(-0.059 \pm 0.013 /$ decade at $99 \%$ confidence level), and the North China Plain $(-0.007 \pm 0.021$ /decade), but a positive increasing trend was identified in northern Xinjiang $(0.01 \pm 0.006 /$ decade), southern Xinjiang $(0.002 \pm 0.013 /$ decade), East China $(0.053 \pm 0.042 /$ decade), and Northeast China $(0.016 \pm 0.029 /$ decade). Seasonal patterns in the AOD regional long-term trend were evident. The AODs in spring over all the study regions, except East China, exhibited a decreasing trend, with the maximum trend value observed in Northwest China $(-0.099 \pm 0.029$ /decade at $99 \%$ confidence level); whereas AODs in autumn, except in Northwest China, showed an increasing trend, with the maximum trend value occurring in East China ( $0.073 \pm 0.038 /$ decade). Geographically, we also examined the annual and seasonal spatial patterns of AOD trends over North China. The annual spatial trends in AOD revealed a dominance of positive trends in most regions over the whole of North China from 2001 to 2016, but especially in East and Northeast China (AOD trend value of about 0.16/decade); whereas a negative trend was observed over northern Inner Mongolia (AOD trend value of about $-0.12 /$ decade). In addition, seasonal spatial trend analyses indicated that a continual clear upward trend occurred in East China in the autumn and winter seasons during the study period, with the maximum average increase occurring in winter (about 0.20/decade).
\end{abstract}

Keywords: AOD; trend; MODIS; long-terms; North China

\section{Introduction}

Aerosol particles, including anthropogenic and natural aerosols, have a crucial effect on global and regional climate change by scattering and absorbing both solar and terrestrial radiation (known as 
the direct effect), depending on the particles' size, shape, chemical composition, and mixing state [1,2], as well as by modifying the microphysical formation and lifetime of clouds, their precipitation efficiency, and hence their radiative properties (known as the indirect effect) [3,4]. In addition, aerosols have an important effect on greenhouse gas concentrations, distributions, and the hydrological cycle by influencing the physical and chemical processes in the atmosphere $[5,6]$. Furthermore, aerosols can cause environmental and public health problems [7,8]. Despite extensive efforts to analyze the sources, properties, and evolution processes of aerosols in recent years, aerosol optical properties and their concentrations are still one of the largest sources of uncertainty in current assessments of global climatic change [9-11].

Aerosol optical depth (AOD), as one of the most basic optical parameters, is both accurate and widely available, and is a key parameter for estimating aerosol content and evaluating the extent of air pollution. As a column-integrated quantity, AOD reflects the aerosol column loading and the impact of aerosols on the Earth's radiation budget. Currently, ground-based observations and satellite monitoring are two important methods for measuring long-term aerosol properties [12]. However, due to a sparse surface network, in-situ observations of aerosol properties and concentrations from various related instruments are difficult to achieve on a continuous and global scale. In recent decades, the retrieval of aerosol optical parameters from satellite observations has attracted more and more interest.

The aerosol products retrieved from the Moderate Resolute Imaging Spectroradiometer (MODIS) provide excellent global coverage, with daily or near-continuous temporal resolution. In contrast to previous studies, the present study analyzed the trends and variability in AOD over North China using the monthly mean of the combined Dark Target/Deep Blue (DT/DB) 550-nm AOD from MODIS Terra, the most recent (as of 2016) data collection 6 (C6), which is based on refined retrieval algorithms [13] and provides extended spatiotemporal coverage compared to earlier products. The performance of the MODIS DT/DB C6 AOD products was recently evaluated through comparison with the ground-based observations of AERONET over China [14]. The research results suggested that collocated AOD retrieved from DT was much higher than that from $\mathrm{DB}$, with the difference in AOD seasonal mean values exceeding 0.3-0.4 over eastern China. In addition, the collocated AOD retrieved from DB enabled a large increase in spatial coverage, especially in conditions of dense haze clouds [14]. Over recent years, various studies have been conducted to determine the long-term variation trends in AOD using a variety of aerosol products retrieved by satellite-based remote sensing. Based on 22 years (1980-2001) of TOMS and 9 years (2000-2008) of MODIS AOD data, a significant increase in AOD was observed across China between 1980 and 2008 [15]. Using the MODIS 3-km observations from 2002 to 2015, research conducted by He et al. (2016) suggested that, pre-2008, there was an upward tendency, while post-2008 there was a downward tendency [16]. Meanwhile, over the Middle East, a previously identified positive AOD trend was also observed based on MODIS C6 products between 2001 and 2012 [17].

With rapid economic and societal development in China, the dramatic increase in industrial and agricultural activities, energy consumption, and the population has inevitably been accompanied by substantial emissions of anthropogenic aerosols into the atmosphere. As a consequence, the aerosols over North China comprise different types, including dust, sulfate and carbonaceous aerosols. Under highly mixed conditions, a complex aerosol loading will be produced in the troposphere [18]. Thus, in order to strengthen our understanding of aerosol responses to climate change and feedback, it is vital to analyze the long-term trends and variability in AOD over North China in recent decades. In this paper, we examine the spatial and temporal variations of annual and seasonal mean AOD distributions over North China using the latest 16 years of combined DT/DB AOD from MODIS Terra, C6. Meanwhile, we also present a long-term annual and seasonal trend analysis of AOD in seven typical regions of North China. 


\section{Data and Methodology}

\subsection{Study Area}

We conducted spatiotemporal variation trend analysis of MODIS AOD at $550 \mathrm{~nm}$ during 2001-2016 for the entire area of North China. Generally, it is easier to distinguish the long-term variation tendencies for different sub-regions, not only because mainland North China covers a very wide area with complex terrain, but also because they are likely to be higher than those in the global AOD averages [15,16,19]. As such, seven typical areas (see Figure 1) in North China were selected for long-term trend analysis: (1) northern Xinjiang; (2) southern Xinjiang; (3) Qinghai Tibet; (4) Northwest China; (5) North China Plain; (6) East China; and (7) Northeast China.

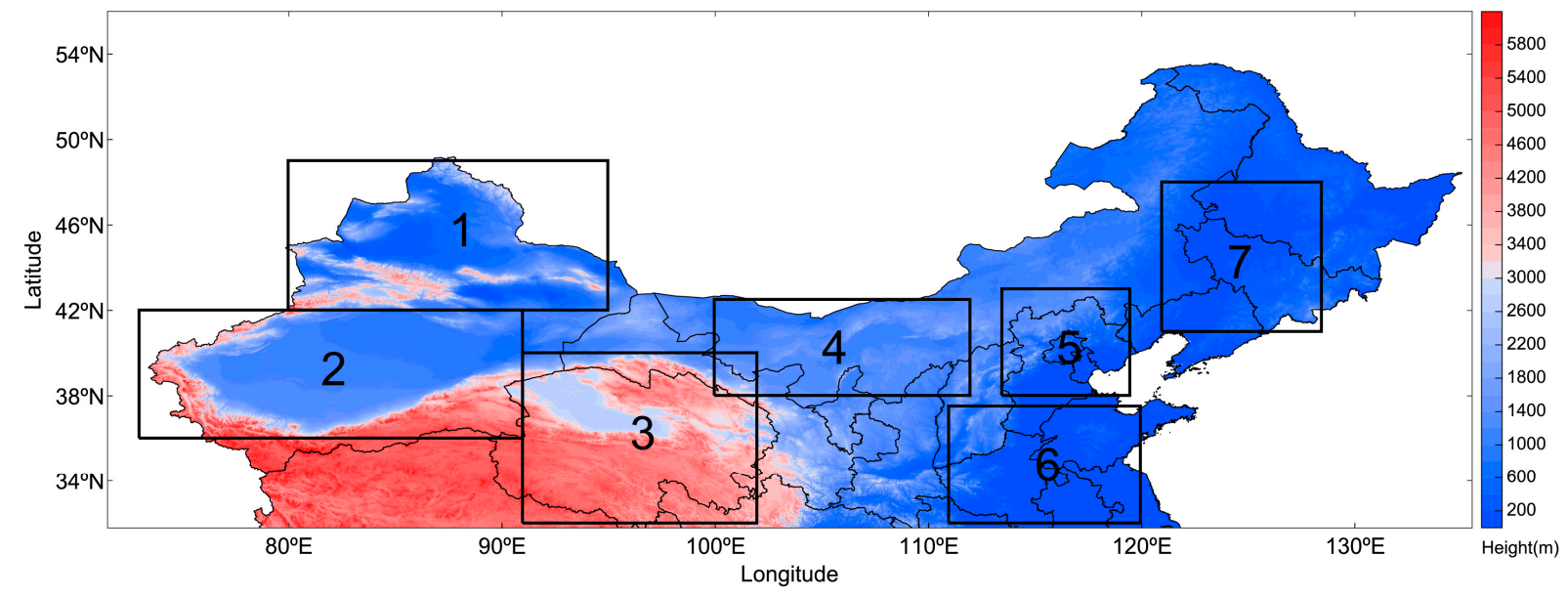

Figure 1. Terrain elevation and location of the seven regions in North China used in this study: northern Xinjiang (1); southern Xinjiang (2); Qinghai Tibet (3); Northwest China (4); North China Plain (5); East China (6); and Northeast China (7).

Northern Xinjiang, southern Xinjiang, Qinghai Tibet, and Northwest China are mainly dominated by natural dust aerosol. Along with the development of atmospheric circulation and weather systems, these dust aerosols enter the atmosphere every spring and are subsequently transported to other regions and further result in dust storm events. North China Plain, East China, and Northeast China are the most highly developed areas, and are more affected by anthropogenic activities, including vehicular emissions, coal combustion, industrial emissions, and biomass burning [20,21], which are the major contributors to air pollution.

\subsection{MODIS C6 AOD Data}

The twin MODIS sensors are located on board the Terra and Aqua satellites, which have been flying in polar orbit since 2000 and 2002, respectively. The MODIS instrument has one wide spectral range in 36 spectral bands, from $0.41 \mu \mathrm{m}$ to $14.5 \mu \mathrm{m}$, with a broad swath $(2330 \mathrm{~km})$ and spatial resolutions of $1 \mathrm{~km}$ (or less, depending on the band). These features permit accurate and useful retrieval of AOD over land and ocean [22,23]. The latest C6 MODIS aerosol products over land and ocean provide refined algorithms for retrieving aerosol properties_-in particular, the expanded Deep Blue algorithm [13,24]. The latter is of special importance for this study, since it is suited for retrievals over 'bright object' surfaces such as the deserts, arid regions, and plateaus covering wide parts of North China. The C6 product introduces the merged DT/DB product, which produces a consistent dataset covering a multitude of surface types, ranging from oceans to bright deserts. In addition, it will not only include the standard 10-km aerosol retrieval product, but also a global (DT-land and DT-ocean) aerosol product at $3 \mathrm{~km} \mathrm{[24].} \mathrm{The} \mathrm{C6} \mathrm{DT-land} \mathrm{expected}$ error is $\pm\left(0.05+0.15 \tau_{\text {AERONET }}\right)$ relative to the AERONET optical thickness $\left(\tau_{\text {AERONET }}\right)$ [24]. The C6 $\mathrm{DB}$ expected error is about $\pm\left(0.03+0.2 \tau_{\text {MODIS }}\right)$ relative to the MODIS optical thickness $\left(\tau_{\text {MODIS }}\right)[13,25]$. 
In addition, it is noted that the drift in the MODIS/Terra blue channel has been correted from C5 to C6 [24]. In this study, the level-3 monthly averaged combined DT/DB AOD data at $550 \mathrm{~nm}$, with a spatial resolution of $1^{\circ} \times 1^{\circ}$ (which can be downloaded from http://modis-atmos.gsfc.nasa.gov/MOD08_M3/index.html), from MODIS Terra C6, for the 16-year period between 2001 and 2016, were used to explore the trends and variability in AOD over North China.

In this study, the annual averaged AOD data were obtained by averaging the monthly AOD data. Furthermore, the seasonal means were obtained for spring (March, April, and May), summer (June, July, and August), autumn (September, October, and November), and winter (December, January, and February) by averaging the monthly means in each season. Based on the annual or seasonally averaged MODIS AOD data, the annual and seasonal linear trends in AOD were estimated using the least-squares linear regression method. This method is based on determining the equation of best fit to time series data by minimizing the sum of the squares of the errors in the residuals. For each trend estimate, Student's t-test was applied to detect the robustness of the trend estimates.

\section{Results and Discussion}

\subsection{Annual and Seasonal Mean AOD Distributions}

As an important optical parameter for aerosols, AOD basically represents the aerosol load in the atmosphere. Figure 2 presents an overview of the annually averaged AOD distribution pattern over North China during 2001-2016. It was computed from the monthly mean products of the combined DT/DB AOD from MODIS Terra, C6. This spatial pattern of annually averaged AOD is generally characterized by two prominent high-value centers. The highest AOD center (between 0.65 and 1) occurred over the North China Plain and East China (also see Figure 1), which are located in the most densely populated and industrialized areas over North China, with low elevations and high anthropogenic aerosol emissions [26]. In the highest AOD regions, large amounts of fine-particle aerosols from anthropogenic activities account for a large proportion of the total aerosol loading. Other important aerosol sources are the high emissions of coarse-particle aerosols, including industrial dust, soot from domestic coal combustion, and dust transported from the desert [16]. The second-highest AOD center (between 0.35 and 0.6) was in the Tarim Basin of southern Xinjiang, with high concentrations of natural aerosols, which could be dominated by desert dust emitted from the Taklimakan Desert. The areas with the lowest AOD $(<0.25)$ were located mainly in northern Qinghai Tibet, Northwest China, and eastern Inner Mongolia. Since these areas are sparsely populated and limited in industrial aerosol emissions, the aerosol loadings are low throughout the year over these regions. The 16-year domain-averaged statistics of the annual and seasonal mean AODs in North China over all seven regions are shown in Figure 3. According to Figure 3, the multi-year averaged AOD of the period 2001-2016 over North China was $0.318 \pm 0.022$. The annually averaged strengths of AOD over North China varied from east to west, with the maximum in East China (0.782 \pm 0.077$)$, followed by the North China Plain $(0.402 \pm 0.036)$, and then Northeast China $(0.342 \pm 0.051)$, southern Xinjiang $(0.315 \pm 0.023)$, Northwest China $(0.224 \pm 0.035)$, Qinghai Tibet $(0.199 \pm 0.018)$, and northern Xinjiang $(0.185 \pm 0.011)$. 


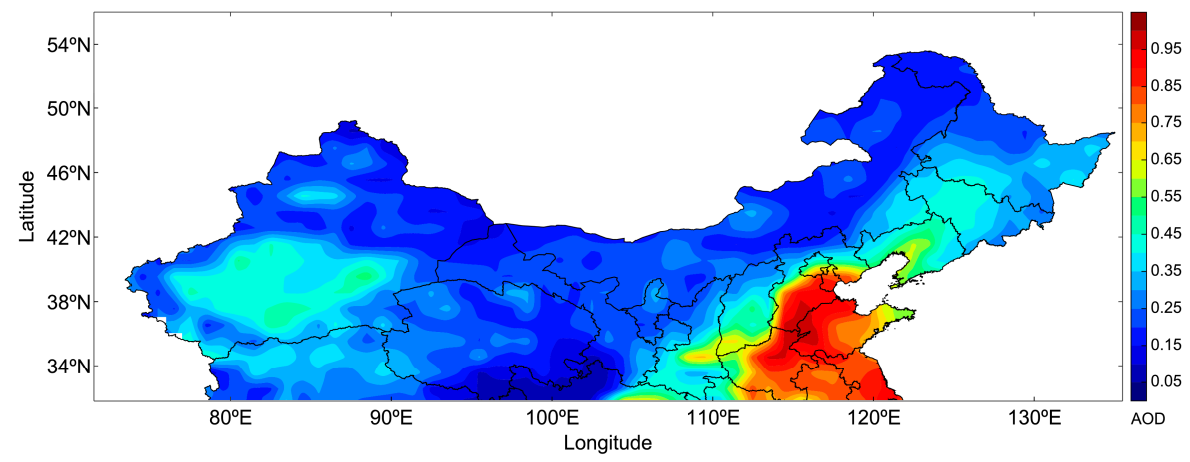

Figure 2. Annual mean AOD at $550 \mathrm{~nm}$ over North China for the period 2001-2016.

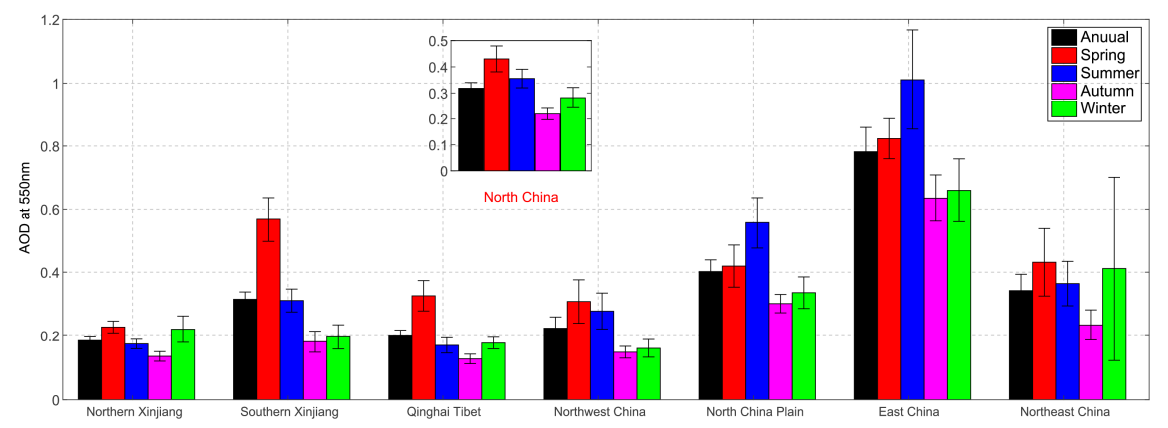

Figure 3. Annual and seasonal mean values of MODIS AOD for the period 2001-2016 in North China and the seven regions (see Figure 1).

Figure 4 shows the spatial distribution of 16-year averaged AOD for spring, summer, autumn, and winter over North China. The spatial distribution of seasonally averaged AOD was similar to the spatial pattern of the multi-year averaged AOD. In all four seasons, the highest AOD loadings were usually located in the North China Plain and East China. The seasonally averaged AOD over North China varied from spring to winter, with the maximum in spring $(0.430 \pm 0.049)$, followed by summer $(0.356 \pm 0.035)$, and then winter $(0.282 \pm 0.039)$ and autumn $(0.219 \pm 0.022)$ (see Figure 3$)$. This seasonal pattern indicates that spring may be the most polluted season over North China, possibly due to the peak dust aerosol loading transported from the deserts in Northwest China, high levels of biomass burning, and fugitive dusts from natural surfaces in spring. The second-highest AOD levels occurred in summer, which can be explained by stronger photochemical interactions owing to higher air temperatures, higher amounts of water vapor, and droplets suspended in the atmosphere during summer $[27,28]$. These factors favor the increase in aerosol loading during this season.
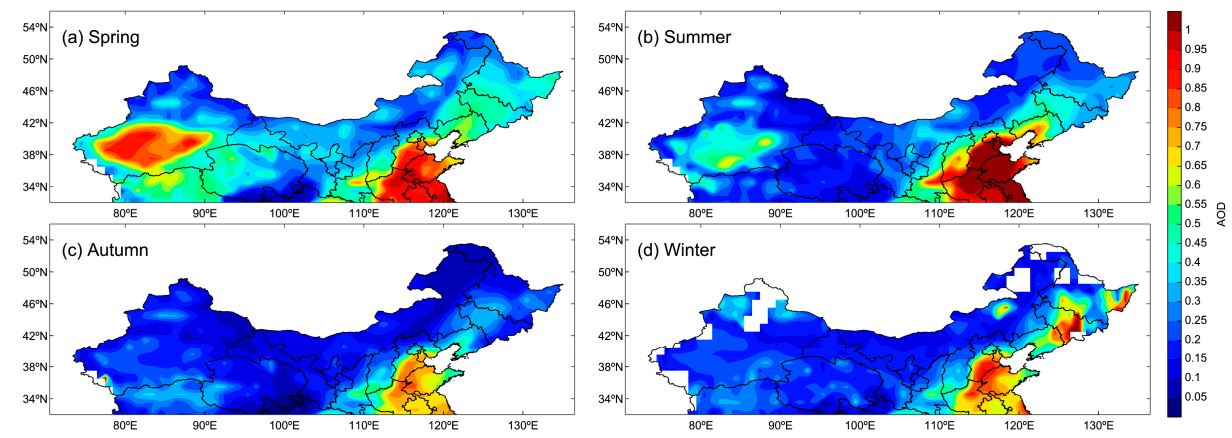

Figure 4. Seasonal mean AOD over North China in (a) spring, (b) summer, (c) autumn, and (d) winter, for the period 2001-2016. 


\subsection{Domain-Averaged Monthly Variations and Seasonal Characteristics in $A O D$}

Figure 5 illustrates in detail the temporal changes in AOD over all seven regions (see Figure 1), both annually and monthly, from January 2001 through to December 2016. Over the whole study period, low aerosol levels prevailed in regions where local natural aerosol particles dominate, such as regions 1, 3 and 4. Relatively high AOD values were seen in regions where dust particles prevail, such as region 2, while much higher aerosol loadings were observed in regions where industrial particles dominate, such as regions 5, 6 and 7. In northern Xinjiang, the monthly AOD values were mostly less than 0.40 throughout the whole study period, which may be related to lower levels of human activity. In southern Xinjiang, however, the period of March-May featured the highest aerosol loadings, indicating the frequent occurrence of dust events during spring over the Taklimakan Desert of southern Xinjiang [29,30]. Relatively high aerosol loadings occurred during the period of March-May in Qinghai Tibet, and the period of March-August in Northwest China. This could be associated with wind-blown sand and/or dust clouds caused by dust storms during spring and summer over the Taklimakan Desert [30,31].
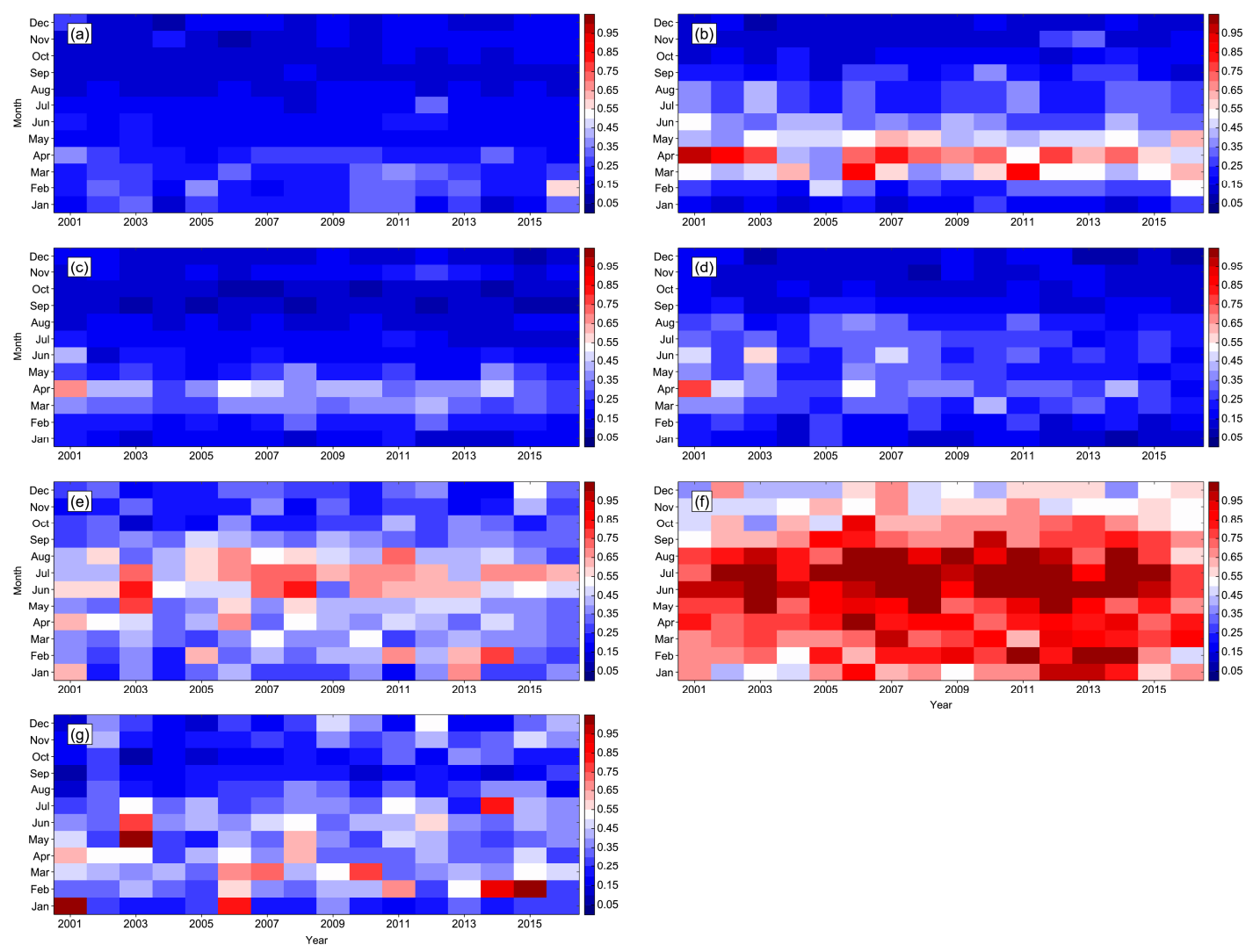

Figure 5. Regional-averaged AOD distribution in relation to month and year in (a) northern Xinjiang, (b) southern Xinjiang, (c) Qinghai Tibet, (d) Northwest China, (e) North China Plain, (f) East China, and (g) Northeast China, for the period 2001-2016.

The notably high AOD values that were observed in April 2001 in both Qinghai Tibet and Northwest China were consistent with the maximum that occurred in April 2001 in southern Xinjiang. Hence, it can be inferred that the dust events that occurred in April 2001 in southern Xinjiang influenced the aerosol loadings of both Qinghai Tibet and Northwest China. Between 2001 and 2016, the North China Plain, with its intensive industrial activities and high population density, tended to be characterized by high aerosol loadings, especially during the period of May-August. The high aerosol content can be explained by hygroscopic particle growth and coagulation, with high temperatures and relative humidity in summer [32]. During the whole period, most of the AOD values (nearly 80\%) were greater than 0.6 in 
East China, with its intensive industrial activities and high population density, reflecting the contribution of particulate matter pollution, especially fine particulate matter with aerodynamic diameters less than $2.5 \mu \mathrm{m}[33,34]$. These results agree with those of Guo et al. (2011) [15]. There were three main peaks in AOD in Northeast China: January 2001, February 2014 and 2015, and May and June 2013. The high aerosol loadings in winter were associated with coal combustion for domestic heating $[35,36]$, while in summer they were related to the hygroscopic growth of aerosols in the humid atmosphere $[37,38]$.

Figure 4 also reveals clear regional characteristics and significant impacts of local aerosol sources. The different seasonal patterns of AOD over the seven regions are shown in Figure 3. Northern Xinjiang had its own seasonal variation, with the maximum aerosol loading in spring $(0.227 \pm 0.018)$ and the minimum in autumn $(0.135 \pm 0.015)$. The seasonal variations in AOD over the whole of North China were similar to those in southern Xinjiang, Qinghai Tibet, and Northwest China, with the maximum AOD in spring, followed by summer and winter, and the minimum in autumn (see Figure 3), reflecting the effect of dust events. The North China Plain and East China showed similar seasonal patterns, with summer having the highest AOD values ( $0.556 \pm 0.079$ and $1.011 \pm 0.156$, respectively) and autumn the lowest AOD values $(0.301 \pm 0.028$ and $0.635 \pm 0.073)$. That the maximum occurred in summer rather than in spring in the North China Plain, and East China is in agreement with previous studies [15,39]. In summer, photochemical interacions are more active, accompanied by higher temperatures and water vapor content, which increases the hygroscopic growth of fine aerosol particles in the atmosphere [27]. In Northeast China, the minimum AOD value $(0.234 \pm 0.047)$ was observed in autumn, while the maximum $(0.431 \pm 0.106)$ was in spring for the study period.

\subsection{Regional Interannual Variation and Trends in $A O D$}

To identify the trends in each of the seven regions over the study period, we carried out a long-term linear trend analysis based on the domain-averaged annual and seasonal mean AOD. Figure 6 displays the average annual and seasonal AOD time series for the period 2001-2016 in the seven regions of North China. On the whole, the annual-averaged AOD time series showed a decreasing tendency, with slopes of $-0.015,-0.059$ (confidence level 99\%) and $-0.007 /$ decade in Qinghai Tibet, Northwest China and the North China Plain, respectively; whereas there were increasing, with trends of $+0.01,+0.002$, +0.053 and $+0.016 /$ decade, in northern Xinjiang, southern Xinjiang, East China and Northeast China, respecctively. Note that, in spring, all seven regions except East China showed a decreasing trend, with the maximum decreasing trend of -0.099 /decade (confidence level 99\%) observed in Northwest China. In contrast, all the seven regions except Northwest China showed an increasing trend in autumn, with the maximum increasing trend of $+0.073 /$ decade observed in East China. In summer, increasing trends of $+0.005,+0.015$ and $+0.036 /$ decade were observed in northern Xinjiang, East China and Northeast China, respectively; whereas, decreasing trends of $-0.027,-0.026$ (confidence level 95\%), -0.088 (confidence level 99\%) and -0.020 /decade were observed in southern Xinjiang, Qinghai Tibet, Northwest China and the North China Plain, respectively. A spurious, abnormally high AOD value was observed in 2016 and 2015 over northern Xinjiang and Northeast China, respectively, possibly due to higher surface albedo in winter [40]. In winter, increasing trends of $+0.033,+0.034$ and $+0.106 /$ decade were observed in southern Xinjiang, the North China Plain and East China, respectively; whereas decreasing trends of -0.004 and -0.035 /decade (confidence level $95 \%$ ) were observed in Qinghai Tibet and Northwest China, respectively. In addition, the annual-averaged AOD was the highest $(>0.60)$ in East China during the study period. It should be noted that Northwest China saw a significant negative trend in all seasons, with a maxiumn decreasing trend of $-0.099 /$ decade (confidence level $99 \%$ ) observed in spring, whereas significant postive trends were seen in East China, with a maxiumn increasing trend of $+0.106 /$ decade in winter. 

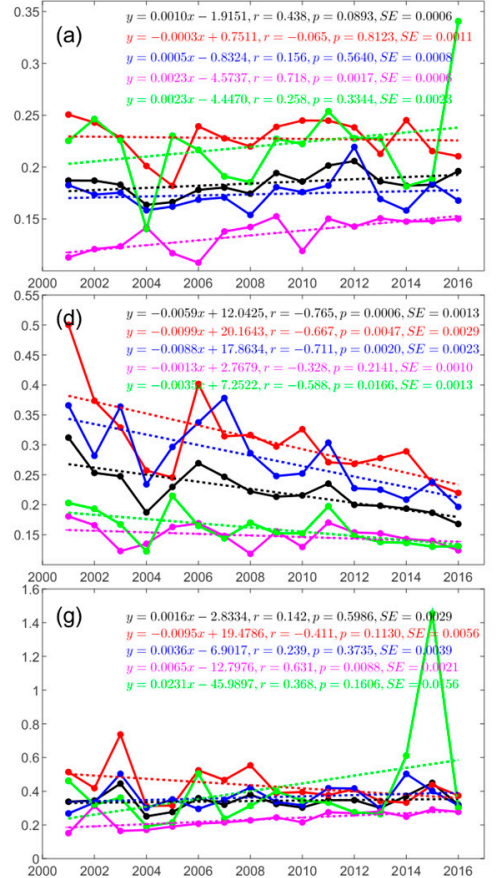
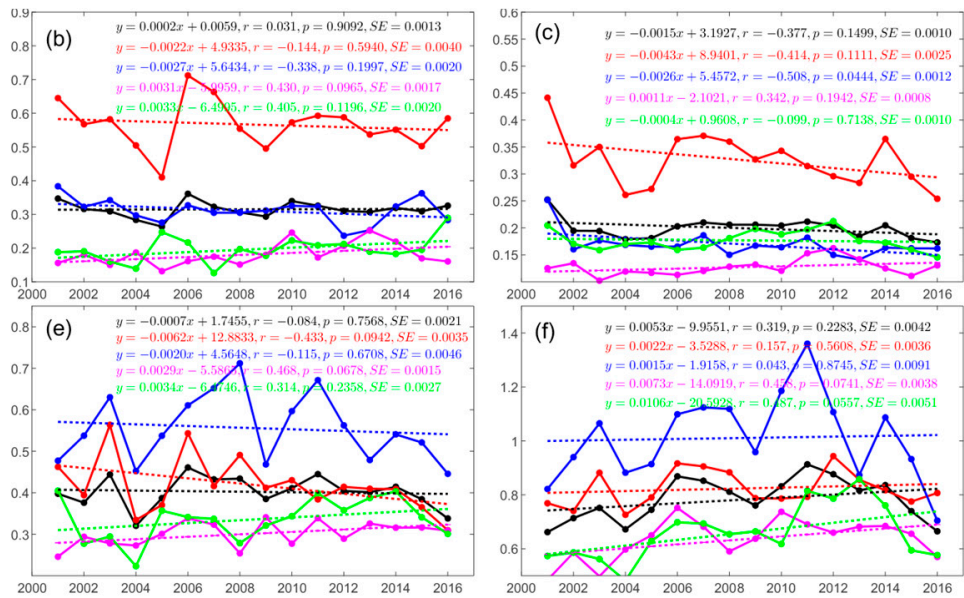

Figure 6. Annual and seasonal AOD time series averaged for the period 2001-2016 for (a) northern Xinjiang, (b) southern Xinjiang, (c) Qinghai Tibet, (d) Northwest China, (e) North China Plain, (f) East China, and (g) Northeast China, together with the slopes, correlation coefficient (r), two-sided p-value (p), and standard error (SE) of the linear trends.

\subsection{Annual and Seasonal Spatial Trends in AOD}

Linear regression trend analysis was performed for the annual and seasonal mean AOD over North China from 2001 to 2016 using the least-squares linear regression method. Figure 7a shows the spatial distributions of the annual trends in MODIS AOD. It can be seen that not all regions have statistically significant trends. In general, the results in Figure 7a reveal positive trends in most regions over North China from 2001 to 2016, especially over the North China Plain, East China, northern Qinghai Tibet, northern Xinjiang, and Northeast China. In particular, there was a notable hot spot of increased AOD in East China, with the increasing trend magnitude ranging from 0.04 to 0.20 /decade between 2001 and 2016. This is due to the rapid increase in industrial and anthropogenic activities over the region $[5,20]$, resulting in more aerosols being emitted into the atmosphere. Comparably strong trends can also be found over the Middle East [17]. In contrast, a significant decreasing trend was observed over northern Inner Mongolia during the study period, with the decreasing trend magnitude ranging from -0.02 to -0.16 /decade. These results may linked to the large decreases in dust emissions caused by decreased wind speed in recent years [41]. In order to help study the radiative effects of aerosols on Earth's climate, we also calculated the corresponding meridionally averaged trends (averaged from $33^{\circ} \mathrm{N}$ to $54^{\circ} \mathrm{N}$ over North China, as shown by the map boundaries of Figure 7a), and these are displayed in Figure $7 \mathrm{~b}$. As expected, the meridionally averaged trends were significantly negative around $100^{\circ}-114^{\circ} \mathrm{E}$, reflecting the decreasing trends in Northwest China. However, the meridional averages showed positive trends around $115^{\circ}-120^{\circ} \mathrm{E}$ and $125^{\circ}-138^{\circ} \mathrm{E}$, representing the increasing trends in East China and Northeast China. It should be mentioned that these meridionally averaged trends might be of high uncertainty, as they are partly based on non-significant trends in some regions of North China. 

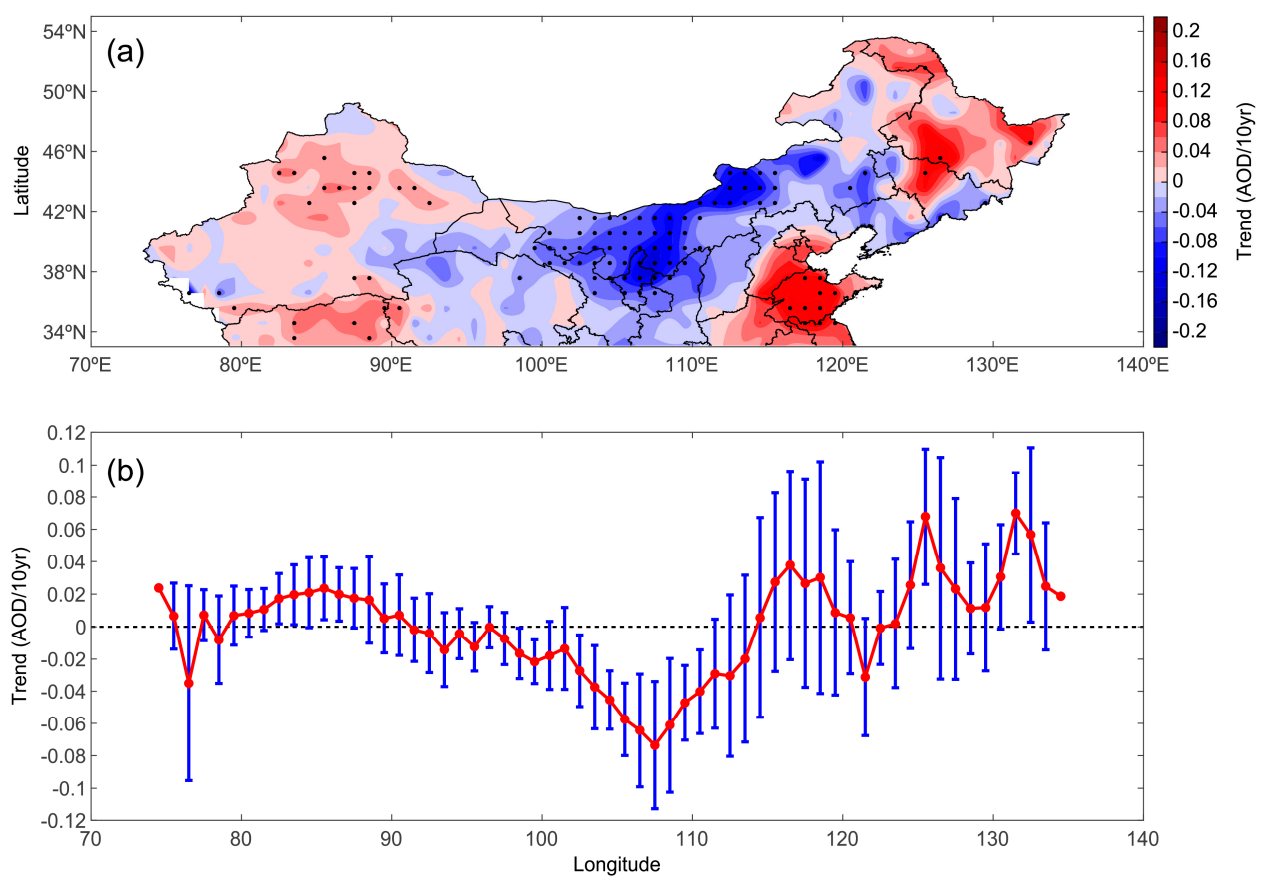

Figure 7. Annual spatial distributions of linear trends from MODIS AOD over North China from 2001 to 2016 (a), and the corresponding meridionally averaged trends (b). Dots indicate significance at 95\% confidence level.

As shown in Figure 4, there is strong seasonality in the emission intensities of natural and anthropogenic aerosols over various source areas, which has a significant impact on large-scale aerosol distributions. Here, we calculated the trends separately for each season based upon the 16-yr MODIS AOD data record; these trends are displayed in Figure 8a,b,e,f. It was found that there were not statistically significant trends in all seasons in North China. There was a clear increasing AOD trend over East China in autumn and winter seasons from 2001 to 2016, with the maximum average increase occurring in winter (about $0.20 /$ decade) and the minimum occurring in spring (about $0.06 /$ decade). However, we only found strong negative trends over northern Inner Mongolia during the spring and summer seasons (about $-0.018 /$ decade and -0.14 /decade, respectively). Similar trend patterns over most areas of North China except for Northeast China were observed, with increasing trends occurring in northern Qinghai Tibet, northern Xinjiang, and East China, but decreasing trends in northern Inner Mongolia. In autumn, an increasing trend was observed over most regions of North China, especially in northern Xinjiang, East China, and Northeast China. The variation trends of AOD in winter were similar to those in autumn.

Similar to Figure $7 b$, the annual meridionally averaged trends are shown in Figure $8 c, d, g, h$. The net negative trends around $90^{\circ}-130^{\circ} \mathrm{E}$ in spring are largely associated with the decreasing dust emissions [39]. The summer meridionally averaged trends were negative in Qinghai Tibet and Northwest China $\left(90^{\circ}-117^{\circ}\right.$ E) due to decreases over the dust source regions [39,41], but were positive in Northeast China $\left(120^{\circ}-135^{\circ} \mathrm{E}\right)$. In general, the autumn meridionally averaged trends were positive, corresponding to the increasing AOD, while the AOD showed decreasing trends in Northwest China $\left(103^{\circ}-110^{\circ} \mathrm{E}\right)$. The notably positive trends around $114^{\circ}-120^{\circ} \mathrm{E}$ during winter are indicative of the increasing pollution emissions in East China. Southern Xinjiang $\left(75^{\circ}-90^{\circ}\right.$ E) showed weak increasing trends, while Northwest China $\left(100^{\circ}-110^{\circ}\right.$ E) showed weak decreasing trends, in winter. It should be noted that the the above annual meridionally averaged trends in four seasons still need to be confirmed in the future, because of the non-significant statistics for the whole North China region. 

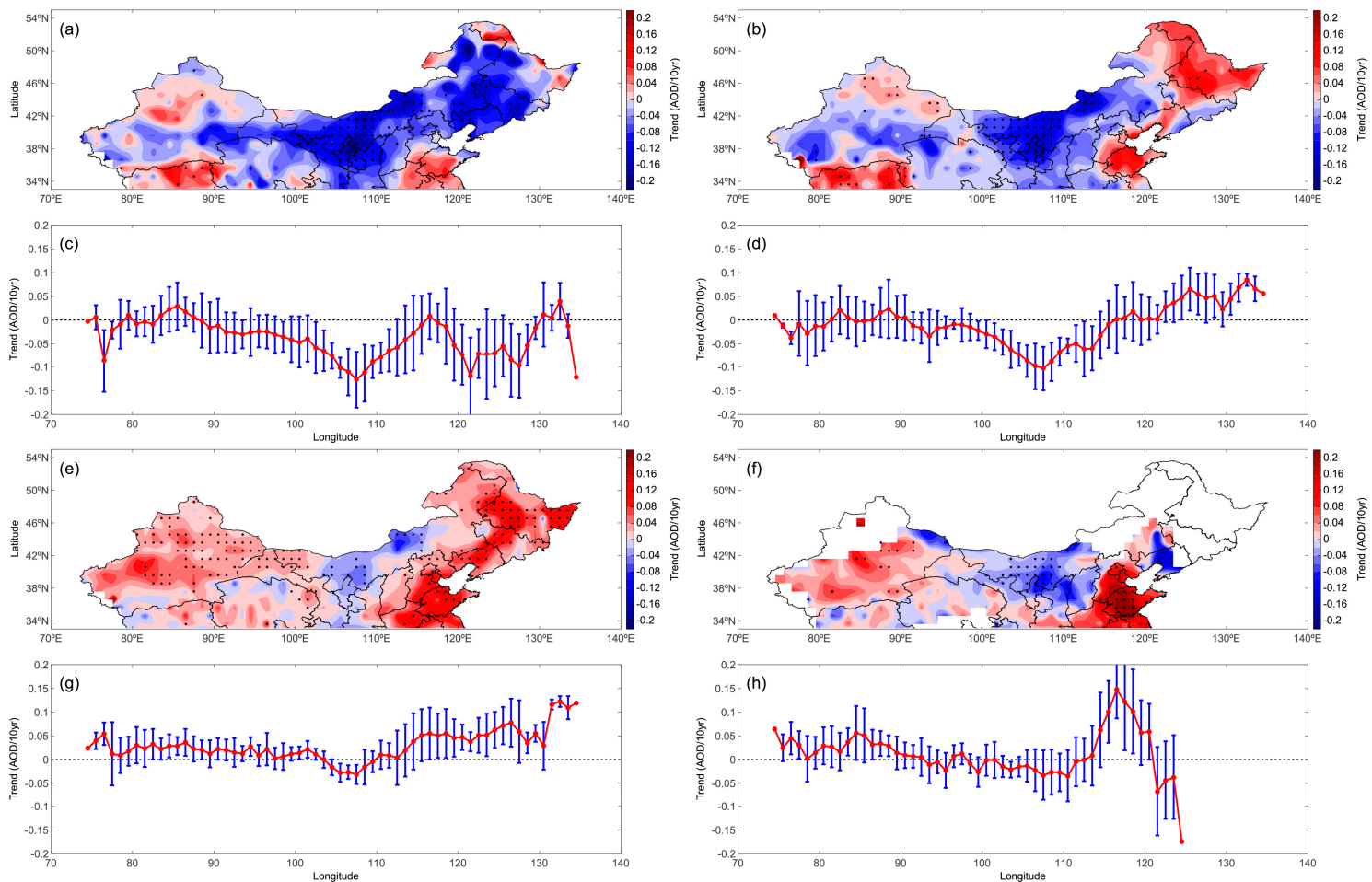

Figure 8. Seasonal spatial distributions of linear trends from MODIS AOD over North China and the corresponding meridionally averaged trends in $(\mathbf{a}, \mathbf{c})$ spring, $(\mathbf{b}, \mathbf{d})$ summer, $(\mathbf{e}, \mathbf{g})$ autumn, and $(\mathbf{f}, \mathbf{h})$ winter, for the period 2001-2016. Dots indicate significance at 95\% confidence level.

\section{Conclusions}

This paper presents the distributions of annual and seasonal mean AOD at $550 \mathrm{~nm}$, as well as the interannual variations and trends in AOD, over seven regions across North China, using the latest MODIS/Terra C6 merged DT/DB AOD data from 2001 to 2016. Insights into the spatial distribution pattern and long-term variations and trends, both spatially and temporally, in regional AOD over North China, have been gained.

Our observations suggest that the annually averaged AOD over North China is generally characterized by two prominent high-value centers located in the North China Plain and East China, with high anthropogenic aerosols (ranging from 0.65 to 1), and in the Tarim Basin of southern Xinjiang, with high natural aerosols (ranging from 0.35 to 0.6 ). Influenced by differences in the level of industry, population density, anthropogenic activities, and elevation, as well as the precipitation and weather systems in the different regions, the levels of seasonal-mean AOD were highest in spring $(0.430 \pm 0.049)$, followed by summer $(0.356 \pm 0.035)$ and winter $(0.282 \pm 0.039)$, and lowest in autumn $(0.219 \pm 0.022)$, during the study period. An investigation into the variations over the seven regions revealed that the maximum seasonal AOD occurred in spring over North China as a whole, and in all regions except the North China Plain and East China, while the maximum seasonal AOD occurred in summer in the other two regions.

The long-term linear trend analysis based on the domain-averaged annual and seasonal mean AOD over the seven regions of North China provided insights into the trend pattern: a decreasing AOD trend prevailed in Qinghai Tibet $(-0.015 \pm 0.010 /$ decade), Northwest China $(-0.059 \pm 0.013 /$ decade at $99 \%$ confidence level), and the North China Plain ( $-0.007 \pm 0.021 /$ decade); whereas, an increasing trend was identified in northern Xinjiang $(0.01 \pm 0.006 /$ decade $)$, southern Xinjiang $(0.002 \pm 0.013 /$ decade $)$, East China ( $0.053 \pm 0.042 /$ decade), and Northeast China ( $0.016 \pm 0.029 /$ decade). In addition, from the temporal perspective, all seven regions showed a decreasing tendency in spring, except East China, with the maximum trend value observed in Northwest China ( $-0.099 \pm 0.029$ /decade); whereas, in autumn, all seven regions except Northwest China presented an increasing trend, with the maximum trend 
occurring in East China ( $0.073 \pm 0.038 /$ decade). From the spatial perspective, the results of the annual and seasonal spatial trends in AOD showed that positive trends dominated in most regions over the whole of North China from 2001 to 2016, but especially in East and Northeast China (AOD trend of about 0.16/decade); whereas a negative trend was observed over northern Inner Mongolia (AOD trend of about $-0.12 /$ decade). Seasonal trend analyses showed that a continual clear upward trend occurred in East China in autumn and winter seasons from 2001 to 2016, with a maximum average increase occurring in winter (about $0.20 /$ decade) and minimum in spring (about $0.06 /$ decade).

Acknowledgments: This work is financially supported by National Key R\&D Program of China (China (2016YFA0601901), National Natural Science Foundation of China (41590874 \& 41375153), Young Talent Project of Heilongjiang Meteorological Administration (2015YT002).

Author Contributions: Peng Wang wrote the article; Shangjun Ning, Jiageng Dai, Jingmin Sun, Yanling Wu, Qingli Song, and Xin Dai conceived and designed the experiments; Hongliang Yuan and Mingjia Lv analyzed the data; Jinrong Zhao and Dajiang Yu helped perform the statistical analysis.

Conflicts of Interest: The authors declare no conflict of interest.

\section{References}

1. Charlson, R.J.; Schwartz, S.E.; Hales, J.M.; Cess, R.D.; Coakley, J.A.; Hansen, J.E.; Hofmann, D.J. Climate forcing by anthropogenic aerosols. Science 1992, 255, 423-430. [CrossRef] [PubMed]

2. Gui, K.; Che, H.; Chen, Q.; An, L.; Zeng, Z.; Guo, Z.; Zheng, Y.; Wang, H.; Wang, Y.; Yu, J.; et al. Aerosol Optical Properties Based on Ground and Satellite Retrievals during a Serious Haze Episode in December 2015 over Beijing. Atmosphere 2016, 7, 70. [CrossRef]

3. Ramanathan, V.; Li, F.; Ramana, M.V.; Praveen, P.S.; Kim, D.; Corrigan, C.E.; Nguyen, H.; Stone, E.A.; Schauer, J.J.; Carmichael, G.R.; et al. Atmospheric brown clouds: Hemispherical and regional variations in long-range transport, absorption, and radiative forcing. J. Geophys. Res. 2007, 112, D22S21. [CrossRef]

4. Li, Z.Q.; Niu, F.; Fan, J.; Liu, Y.; Rosenfeld, D.; Ding, Y. Long-term impacts of aerosols on the vertical development of clouds and precipitation. Nat. Geosci. 2011, 12, 888-894. [CrossRef]

5. Gui, K.; Che, H.; Chen, Q.; Zeng, Z.; Zheng, Y.; Long, Q.; Sun, T.; Liu, X.; Wang, Y.; Yu, J.; et al. Water vapor variation and the effect of aerosols in China. Atmos. Environ. 2017, 165, 322-335. [CrossRef]

6. Luo, Y.; Zheng, X.; Zhao, T.; Chen, J. A climatology of aerosol optical depth over China from recent 10 years of MODIS remote sensing data. Int. J. Climatol. 2014, 4, 863-870. [CrossRef]

7. Tie, X.X.; Wu, D.; Brasseur, G. Lung cancer mortality and exposure to atmospheric aerosol particles in Guangzhou, China. Atmos. Environ. 2009, 43, 2375-2377. [CrossRef]

8. Schäfer, K.; Thomas, W.; Peters, A.; Ries, L.; Obleitner, F.; Schnelle-Kreis, J.; Birmili, W.; Diemer, J.; Fricke, W.; Junkermann, W.; et al. Influences of the 2010 Eyjafjallajökull volcanic plume on air quality in the northern Alpine region. Atmos. Chem. Phys. 2011, 11, 8555-8575. [CrossRef]

9. Ramanathan, V.; Crutzen, P.J.; Lelieveld, J.; Mitra, A.P.; Althausen, D.; Anderson, J.; Andreae, M.O.; Cantrell, W.; Cass, G.R.; Chung, C.E.; et al. The Indian Ocean experiment: An integrated analysis of the climate forcing and effects of the great Indo-Asian haze. J. Geophys. Res. 2001, 106, 28371-28398. [CrossRef]

10. Intergovernmental Panel on Climate Change (IPCC). Climate Change 2007: The Scientific Basis; Forth Assessment Report; Cambridge University Press: New York, NY, USA, 2007; 996p.

11. Intergovernmental Panel on Climate Change (IPCC). Climate Change 2013: The Physical Science Basis; Contribution of Working Group I to the Fifth Assessment Report of the Intergovernmental Panel on Climate Change; Stocker, T.F., Qin, D., Plattner, G.-K., Tignor, M., Allen, S.K., Boschung, J., Nauels, A., Xia, Y., Bex, V., Midgley, P.M., Eds.; Cambridge University Press: Cambridge, UK; New York, NY, USA, 2013; 1535p.

12. Che, H.; Zhang, X.; Xia, X.; Goloub, P.; Holben, B.; Zhao, H.; Wang, Y.; Zhang, X.; Wang, H.; Blarel, L.; et al. Ground-based aerosol climatology of China: Aerosol optical depths from the China aerosol remote sensing network (CARSNET) 2002-2013. Atmos. Chem. Phys. 2015, 15, 7619-7652. [CrossRef]

13. Sayer, A.M.; Munchak, L.A.; Hsu, N.C.; Levy, R.C.; Bettenhausen, C.; Jeong, M.-J. MODIS Collection 6 aerosol products: comparison between aqua's e-deep blue, dark target, and "merged" data sets, and usage recommendations. J. Geophys. Res. Atmos. 2014, 119, 13965-13989. [CrossRef] 
14. Tao, M.; Chen, L.; Wang, Z.; Tao, J.; Che, H.; Wang, X.; Wang, Y. Comparison and evaluation of the MODIS collection 6 aerosol data in China. J. Geophys. Res. Atmos. 2015, 120, 6992-7005. [CrossRef]

15. Guo, J.P.; Zhang, X.Y.; Wu, Y.R.; Zhaxi, Y.; Che, H.Z.; La, B.; Wang, W.; Li, X.W. Spatio-temporal variation trends of satellite-based aerosol optical depth in China during 1980-2008. Atmos. Environ. 2011, 4537, 6802-6811. [CrossRef]

16. He, Q.; Zhang, M.; Huang, B. Spatio-temporal variation and impact factors analysis of satellite-based aerosol optical depth over China from 2002 to 2015. Atmos. Environ. 2016, 129, 79-90. [CrossRef]

17. Klingmüller, K.; Pozzer, A.; Metzger, S.; Stenchikov, G.L.; Lelieveld, J. Aerosol optical depth trend over the Middle East. Atmos. Chem. Phys. 2016, 16, 5063-5073. [CrossRef]

18. Xia, X.A.; Chen, H.B.; Wang, P.C.; Zong, X.M.; Qiu, J.H.; Gouloub, P. Aerosol properties and their spatial and temporal variations over north China in spring 2001. Tellus 2005, 57, 28-39.

19. Zhao, T.X.-P.; Laszlo, I.; Guo, W.; Heidinger, A.; Cao, C.; Jelenak, A.; Tarpley, D.; Sullivan, J. Study of long-term trend in aerosol optical thickness observed from operational AVHRR satellite instrument. J. Geophys. Res. 2008, 113, D07201. [CrossRef]

20. Zhang, R.; Jing, J.; Tao, J.; Hsu, S.C.; Wang, G.; Cao, J.; Lee, C.S.L.; Zhu, L.; Chen, Z.; Zhao, Y.; et al. Chemical characterization and source apportionment of PM2.5 in Beijing: seasonal perspective. Atmos. Chem. Phys. 2013, 13, 7053-7074. [CrossRef]

21. Hsu, N.C.; Gautam, R.; Sayer, A.M.; Bettenhausen, C. Global and regional trends of aerosol optical depth over land and ocean using seawifs measurements from 1997 to 2010. Atmos. Chem. Phys. 2012, 12, 8037-8053. [CrossRef]

22. Remer, L.A.; Kaufman, Y.J.; Tanre, D.; Mattoo, S.; Chu, D.A.; Martins, J.V.; Li, R.R.; Ichoku, C.; Levy, R.C.; Kleidman, R.G.; et al. The MODIS aerosol algorithm, products, and validation. J. Atmos. Sci. 2005, 62, 947-973. [CrossRef]

23. Levy, R.C.; Remer, L.A.; Kleidman, R.G.; Mattoo, S.; Ichoku, C.; Kahn, R.; Eck, T.F. Global evaluation of the Collection 5 MODIS dark-target aerosol products over land. Atmos. Chem. Phys. 2010, 10, 10399-10420. [CrossRef]

24. Levy, R.C.; Mattoo, S.; Munchak, L.A.; Remer, L.A.; Sayer, A.M.; Patadia, F.; Hsu, N.C. The Collection 6 MODIS aerosol products over land and ocean. Atmos. Meas. Tech. 2013, 6, 2989-3034. [CrossRef]

25. Leeuw, G.D.; Sogacheva, L.; Rodriguez, E.; Kourtidis, K.; Georgoulias, A.K.; Alexandri, G.; Amiridis, V.; Proestakis, E.; Marinou, E.; Xue, Y.; et al. Two decades of satellite observations of AOD over mainland China. Atmos. Chem. Phys. Discuss. 2017. in review. [CrossRef]

26. Lei, Y.; Zhang, Q.; He, K.B.; Streets, D.G. Primary anthropogenic aerosol emission trends for China, 1990-2005. Atmos. Chem. Phys. 2011, 11, 931-954. [CrossRef]

27. Dickerson, R.; Kondragunta, S.; Stenchikov, G.; Civerolo, K.; Doddridge, B.; Holben, B. The impact of aerosols on solar ultraviolet radiation and photochemical smog. Science 1997, 278, 827-830. [CrossRef] [PubMed]

28. Li, L.; Wang, Y. What drives the aerosol distribution in Guangdong-the most developed province in Southern China? Sci. Rep. 2014, 4, 5972. [CrossRef] [PubMed]

29. Xue, F.; Liu, X.; Ma, Y.; Zhang, Q. Variation Characteristics of Dust Weather in the Hinterland of Taklimakan Desert during 1997-2007. Desert Oasis Meteorol. 2009, 3, 31-34. (In Chinese)

30. Che, H.; Wang, Y.; Sun, J.; Zhang, X.; Zhang, X.; Guo, J. Variation of aerosol optical properties over the Taklimakan Desert in China. Aerosol Air Qual. Res. 2013, 13, 777-785. [CrossRef]

31. Huang, J.; Minnis, P.; Yi, Y.; Tang, Q.; Wang, X.; Hu, Y.; Winker, D. Summer dust aerosols detected from CALIPSO over the Tibetan Plateau. Geophys. Res. Lett. 2007, 34, L18805. [CrossRef]

32. Yu, X.; Lü, R.; Liu, C.; Yuan, L.; Shao, Y.; Zhu, B.; Lei, L. Seasonal variation of columnar aerosol optical properties and radiative forcing over Beijing, China. Atmos. Environ. 2017, 166, 340-350. [CrossRef]

33. Cheng, Z.; Wang, S.; Jiang, J.; Fu, Q.; Chen, C.; Xu, B.; Hao, J. Long-term trend of haze pollution and impact of particulate matter in the Yangtze River Delta, China. Environ. Pollut. 2013, 182, 101-110. [CrossRef] [PubMed]

34. Ma, Z.; Liu, Y.; Zhao, Q.; Liu, M.; Zhou, Y.; Bi, J. Satellite-derived high resolution PM2.5 concentrations in Yangtze River Delta Region of China using improved linear mixed effects model. Atmos. Environ. 2016, 133, 156-164. [CrossRef] 
35. Zhao, H.; Che, H.; Zhang, X.; Ma, Y.; Wang, Y.; Wang, X.; Liu, C.; Hou, B.; Che, H. Aerosol optical properties over urban and industrial region of northeast China by using ground-based sun-photometer measurement. Atmos. Environ. 2013, 75, 270-278. [CrossRef]

36. Che, H.; Zhao, H.; Wu, Y.; Xia, X.; Zhu, J.; Wang, H.; Wang, Y.; Sun, J.; Yu, J.; Zhang, X.; et al. Analyses of aerosol optical properties and direct radiative forcing over urban and industrial regions in northeast China. Meteorol. Atmos. Phys. 2015, 127, 345-354. [CrossRef]

37. Eck, T.F.; Holben, B.N.; Dubovik, O.; Smirnov, A.; Goloub, P.; Chen, H.B.; Chatenet, B.; Gomes, L.; Zhang, X.Y.; Tsay, S.C.; et al. Columnar aerosol optical properties at AERONET sites in central eastern Asia and aerosol transport to the tropical mid-Pacific. J. Geophys. Res. 2005, 110. [CrossRef]

38. Bian, H.; Chin, M.; Rodriguez, J.M.; Yu, H.; Penner, J.E.; Strahan, S. Sensitivity of aerosol optical thickness and aerosol direct radiative effect to relative humidity. Atmos. Chem. Phys. 2009, 9, 2375-2386. [CrossRef]

39. Herman, J.R.; Bhartia, P.K.; Torres, O.; Hsu, C.; Seftor, C.; Celarier, E. Global distribution of UV-absorbing aerosols from Nimbus 7/TOMS data. J. Geophys. Res. Atmos. 1997, 102, 16911-16922. [CrossRef]

40. Liu, H.; Wang, B.; Fu, C. Relationships between surface albedo, soil thermal parameters and soil moisture in the semi-arid area of Tongyu, northeastern China. Adv. Atmos. Sci. 2008, 25, 757-764. [CrossRef]

41. Yang, Y.; Russell, L.M.; Lou, S.; Liao, H.; Guo, J.; Liu, Y.; Singh, B.; Ghan, S.J. Dust-wind interactions can intensify aerosol pollution over eastern China. Nat. Commun. 2017, 8, 15333. [CrossRef] [PubMed]

(C) 2017 by the authors. Licensee MDPI, Basel, Switzerland. This article is an open access article distributed under the terms and conditions of the Creative Commons Attribution (CC BY) license (http://creativecommons.org/licenses/by/4.0/). 